\title{
Analyzing interspeaker variation in Maay
}

\author{
Mary Paster \\ Pomona College, Claremont, California \\ mary.paster@pomona.edu ORCID: https://orcid.org/0000-0002-9947-4948
}

Submitted: 24/07/2019. Accepted: 3/10/2019. Publicado online: 8/9/2020

Citation / Cómo citar este artículo: Mary Paster (2019). Analyzing interspeaker variation in Maay. Loquens, 6(2), https:// doi.org/10.3989/loquens.2019.063

\begin{abstract}
This paper advocates an approach to interspeaker linguistic variation that aligns with the 'I-language' view (Chomsky, 1986). On this view, the object of study in linguistics is mental grammar; language is understood as being internal to the individual, in contrast to the 'E-language' approach, where language is external to individual speakers. This paper considers a case study from Maay (a Cushitic language spoken in southern Somalia) in which interspeaker variation in a refugee community defies analysis in E-language terms. An I-language approach allows for a straightforward analysis of the observed variation, specifically in the domains of plural noun formation and vowel length alternations.
\end{abstract}

Keywords: Cushitic; E-language; I-language; interspeaker variation; phonological variation.

RESUMEN: Análisis de la variación interhablante en maay-. El presente estudio propugna un enfoque de la variación lingüística inter-hablante acorde con la perspectiva de la 'lengua-I' (Chomsky, 1986). Según esta última, el objeto de estudio de la lingüística es la gramática mental; se considera que el individuo tiene interiorizado el lenguaje, al contrario de lo que defiende el enfoque de la 'lengua-E', en el que el lenguaje es externo a los hablantes individuales. En este artículo se estudia el caso del maay (lengua cusita hablada en el sur de Somalia) y se observa que la variación inter-hablante que se da en una comunidad de refugiados supone un desafío para los análisis en términos de lengua-E. Un planteamiento basado en el enfoque de la lengua-I permite un análisis más simple de la variación observada, concretamente en los ámbitos de la formación del plural en los nombres y de las alternancias en la duración vocálica.

Palabras clave: lengua cusita; lengua-E; lengua-I; variación inter-hablantes; variación fonológica.

\section{INTRODUCTION}

In this paper I argue for an approach to interspeaker linguistic variation that aligns with the 'I-language' view. The term 'I-language' originates in Chomsky, 1986 (see Isac and Reiss, 2008, for a detailed exposition of the concept, as well as Hale, 2007, for discussion of the implications of I-language for the study of diachronic language change). On the I-language view, the object of study in linguistics is mental grammar; language is understood as being internal to the individual. Studies of variation, on the other hand, are generally associated with an 'E-language' approach, referring to 'external' language. On the E-language view, a language is something outside of an individual speaker; it exists in a speech community, in books, and/or in a corpus of spoken or written language. Such a view is implicit in any study that measures the statistical frequency of a pattern in a speech community without keeping data from individual speakers distinct. It is perhaps for this reason that formalists often do not consider interspeaker variation (see Honeybone, 2011, for discussion). However, I will argue that interspeaker variation can be fruitfully analyzed using an I-language approach. In fact, I will argue that taking an I-language approach is the only way to understand variation in some communities. I will focus on the case of Maay, a Cushitic language spoken in southern Somalia, highlighting some aspects of interspeaker variation that are observed in a community of Maay-speaking refugees. I will show how only the I-language approach enables us to make sense of the extreme variation observed within the speech community, specifically in the domains of plural noun formation and vowel length alternations. 


\section{DEFINING VARIATION}

Before we look at the phenomena of interest in Maay, some background is in order regarding what is meant by 'variation'. In this paper I distinguish intraspeaker from interspeaker variation. Some researchers intentionally treat the two as interchangeable for analytical purposes (see, e.g., Guy, 2005, p. 562, for a defense of 'extrapolating within communities from group data to individual grammars'), but most appear to do so less consciously, proceeding from descriptions of community behavior to proposals about grammars (mental objects that necessarily reside within an individual) without explicit acknowledgment of the leap being made. ${ }^{1}$ Guy argues that such extrapolation is warranted because there is evidence that individual grammars do reflect patterns in the speech community, while acknowledging that the extent to which this is true is an open empirical question (2005, p. 562); it should be added that the question is open regarding every speech community, since the degree of similarity across individuals may not be uniform across languages. For example, as Toivonen points out, both inter- and intraspeaker variation are greater in situations of language endangerment/contraction (2007, pp. 363-364; citing Cook, 1989, and Dorian, 1994). ${ }^{2}$

In an I-language approach, interspeaker variation is predicted by the fact that each individual has a unique mental grammar. While members of the same speech community can be expected to have similar mental grammars, no two will be identical. Thus, interspeaker variation is not a characteristic of a language per se but is rather a natural consequence of the fact that language resides in individuals. In the fieldwork context, an advantage of this way of understanding variation is that it allows the researcher to make sense of data from an individual speaker that may seem anomalous in light of utterances produced by other speakers. ${ }^{3}$ Methodologically, this approach necessitates distinguishing the source of every data point in one's field notes (which is good fieldwork practice in any case), keeping individual data distinct when formulating analyses, and attributing data to individuals in published descriptions (whether by name or otherwise, depending on the speaker's preference).

\footnotetext{
${ }^{1}$ It is easy to identify examples of this since they include any descriptive work where multiple speakers are mentioned or thanked but only one grammar is described; this is admittedly true of several of my own papers.

${ }^{2}$ While the statement from Guy (2005) cited above assumes that speech communities may exhibit considerable intraspeaker variation but little interspeaker variation, the reverse is also possible -a community where individual performance is relatively stable but there are notable idiolectal differences across speakers. Formal analyses likely miss many such cases because of the tendency to conflate different types of variation; some notable exceptions include Marlo's (2008) analysis of verbal tone in Tura which systematically describes phonological and morphological differences between two speakers, and Toivonen's (2007) paper on verbal inflection in Inari Saami which addresses morphological differences among three speakers.

${ }^{3}$ Thanks to an anonymous reviewer for making this point.
}

\section{MAAY LANGUAGE BACKGROUND}

Maay (a.k.a. Af-Maay, MayMay; Paster, 2007; Comfort and Paster, 2009; Paster, 2010) is a Cushitic language related to, but not mutually intelligible with, Somali. The varieties of Maay described in this paper reflect the speech of a group of refugees identifying as 'Somali Bantus' who now live in the United States. Their speech has doubtless been influenced in a variety of ways by their linguistic and personal experiences as refugees, so no claim will be made regarding the relationships between these varieties of Maay and those still spoken in Somalia. The Maay language is also being lost from at least some of these US Somali Bantu communities; in San Diego, for example, the children are not learning Maay (Paster et al., 2013). These factors may account for the extreme degree of interspeaker variation exhibited by my consultants.

Ten Maay speakers in the United States were consulted during the course of this project; data from six of them appear in this paper. Some demographic data on these speakers is given in Table 1; their ages are given as of 2012-13 when the main data were collected (except where noted). Speaker OM lived in Pittsburgh, Pennsylvania, and was the source of the data in Paster, 2007; Comfort and Paster, 2009; and Paster, 2010; the remaining speakers lived in San Diego, California at the time of the research.

Table 1: Participants.

OM, male, 27 at time of research in 2007, from Kowan (near Jamaame), speaks Maay, Zigua, Swahili, English

HJ, male, mid-30s, from Jamma (spent time in Kenya); speaks Maay, Zigua, English, Somali

BM, female, 48, from Jamaame; speaks Maay, Zigua, Somali, English, some Swahili

LJ, male, 52, from Jamaame; speaks Maay, Zigua, Somali, English, Swahili, Italian, some Spanish

AM, male, 27, from Kismaayo (spent time in Kenya); speaks Maay, Zigua, Somali, English, Swahili, Turkana, Giryama

HA, female, 30s, from Jamaame (grew up in Kenya); speaks Maay, Zigua, Swahili, English

As can be seen in Table 1, most of the participants are from Jamaame, but many reported spending considerable time in refugee camps in Kenya. Of the nine San Diego consultants, eight of them are related to each other by blood or marriage, and all lived within one mile of each other as of 2013 .

\section{VARIATION IN PLURAL MARKING}

The first aspect of variation discussed here will be a pattern of variable plural marking on nouns. In this section, I will present each speaker's plural data individually, followed by a comparison across speakers. 
Speaker OM, the speaker consulted in Pittsburgh in 2007, produced the following patterns of plural marking on nouns (documented in Paster, 2007; Comfort and Paster, 2009; and Paster, 2010). First, as shown in (2), consonant-final stems have three plural forms in free variation. No exceptions were observed, and no semantic or functional distinctions were identified for the different forms. $^{4}$

$\begin{array}{llll}\text { mukulal-yal } & \sim \text { mukulal-o } & \sim \text { mukulal-o-yal } & \text { 'cats' } \\ \text { eey-yal } & \sim \text { eey-o } & \sim \text { eey-o-yal } & \text { 'dogs' } \\ \text { geet-yal } & \sim \text { geeð-o } & \sim \text { geeð-o-yal } & \text { 'trees' } \\ \text { ees-yal } & \sim \text { ees-o } & \sim \text { ees-o-yal } & \text { 'grasses' } \\ \text { miis-yal } & \sim \text { miis-o } & \sim \text { miis-o-yal } & \text { 'tables' } \\ \text { kuras-yal } & \sim \text { kuras-o } & \sim \text { kuras-o-yal } & \text { 'chairs' } \\ \text { hidik-yal } & \sim \text { hidiy-o } & \sim \text { hidiy-o-yal } & \text { 'stars' }, \\ \text { basal-yal } & \sim \text { basal-o } & \sim \text { basal-o-yal } & \text { 'onions' } \\ \text { af-yal } & \sim \text { af-o } & \sim \text { af-o-yal } & \text { 'mouths' } \\ \text { kawaf-yal } & \sim \text { kawaf-o } & \sim \text { kawaf-o-yal } & \text { 'cabbages' } \\ \text { eren-yal } & \sim \text { erem-o } & \sim \text { erem-o-yal } & \text { 'goats' } \\ \text { yahas-yal } & \sim \text { yahas-o } & \sim \text { yahas-o-yal } & \text { 'crocodiles' } \\ \text { buubun-yal } & \sim \text { buubun-o } & \sim \text { buubun-o-yal } & \text { 'snails' } \\ \text { bin-yal } & \sim \text { bin-o } & \sim \text { bin-o-yal } & \text { 'pins' }\end{array}$

In contrast, for this speaker, vowel-final stems can only form their plural with -yal, as shown in (3). Again, no exceptions were observed.

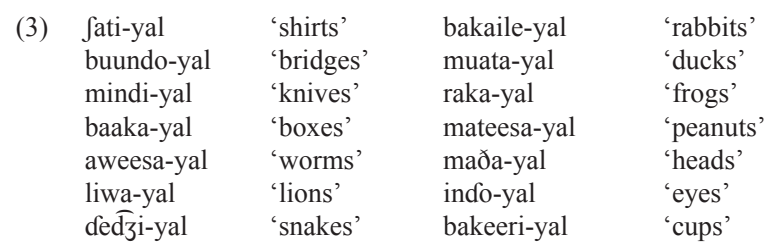

Thus, speaker OM has a phonologically conditioned distribution for the two suffix allomorphs, such that $-o$ is restricted to occurring after consonant-final nouns, but $-y a l$ can occur with any noun (even one that already bears the $-o$ suffix).

Some different patterns were observed among the speakers in the San Diego group. Speaker BM has similar patterns to $\mathrm{OM}$ with some interesting differences. Like $\mathrm{OM}$, as can be seen in (4), BM gives only the $-y$ al form for most vowel-final nouns.

\footnotetext{
${ }^{4}$ For all plural examples, a singular form can be produced in isolation (and was elicited, in all cases). The singular can be straightforwardly inferred from the plural by removing the plural suffix(es). The only exceptions to this are (1) some irregular plurals that are morphologically unrelated to the singular, which are not included in this paper, and (2) some regular phonological alternations to stem-final consonants resulting from intervocalic stop lenition (see Paster, 2007, for details). Where a $-y a l$ plural exists, the singular is always identical to that form minus the plural suffix (since -yal, in contrast to $-o$, does not create a context for lenition to apply to the stem-final consonant).

${ }^{5}$ Here and throughout the paper, an asterisk indicates forms that were explicitly rejected by the speaker.
}

\begin{tabular}{|c|c|c|c|c|c|}
\hline (4) mindi- & *mind-o & *mindi-o & $\begin{array}{l}\text { *mind-o- } \\
\text { yal }\end{array}$ & $\begin{array}{l}\text { *mindi-o- } \\
\text { yal }\end{array}$ & 'knives' \\
\hline $\begin{array}{l}\text { farkeeti- } \\
\text { yal-ki }\end{array}$ & *farkeeð-o & *farkeeti-o & $\begin{array}{l}\text { *farkeeð- } \\
\text { o-yal }\end{array}$ & $\begin{array}{l}\text { *farkeeti- } \\
\text { o-yal }\end{array}$ & 'forks' \\
\hline woßi-yal & ${ }^{*}$ wo $\beta-\mathrm{o}$ & *wo $\beta$ i-o & $\begin{array}{c}{ }^{*} \text { wo } \beta-o- \\
\text { yal }\end{array}$ & $\begin{array}{l}\text { *woßi-o- } \\
\text { yal }\end{array}$ & 'rivers' \\
\hline raka-yal & *rak-o & *raka-o & *rak-o-yal & *raka-o-yal & 'frogs' \\
\hline $\begin{array}{l}\text { maða- } \\
\text { yal-ki }\end{array}$ & *mað-о & *maða-o & $\begin{array}{l}\text { *mað-o- } \\
\text { yal-ki }\end{array}$ & $\begin{array}{l}\text { *maða-o- } \\
\text { yal }\end{array}$ & 'heads' \\
\hline fura-yal & $*$ fur-o & * fura-o & *fur-o-yal & *fura-o-yal & 'keys' \\
\hline $\begin{array}{l}\text { bakaile- } \\
\text { yal-ki }\end{array}$ & *bakail-o & *bakaile-o & $\begin{array}{l}\text { *bakail-o- } \\
\text { yal }\end{array}$ & $\begin{array}{l}\text { *bakaile-o- } \\
\text { yal }\end{array}$ & 'rabbits' \\
\hline $\begin{array}{l}\text { embe- } \\
\text { yal-ki }\end{array}$ & *emb-o & *embe-o & $\begin{array}{l}\text { *emb-o- } \\
\text { yal }\end{array}$ & $\begin{array}{l}\text { *embe-o- } \\
\text { yal }\end{array}$ & 'mangos' \\
\hline
\end{tabular}

For a small set of vowel-final nouns, it is also possible to replace the final vowel with - $O$; in these cases the -o-yal form is also possible, as seen in (5). No such forms were recorded from OM.

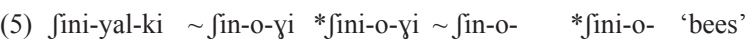

$$
\begin{aligned}
& \text { yal-ki yal-ki } \\
& \text { kora-yal-ki } \sim \text { kor-o } \quad \text { *kora-o } \sim \text { kor-o- *kora-o- '(monkey } \\
& \text { yal-ki yal-ki species)' }
\end{aligned}
$$

My analysis is that for BM, these particular nouns have two separate underlying forms in free variation - one with the final vowel and one without (e.g., / / ini/ / / in/), which behave like normal vowel-final and consonant-final roots, respectively.

For most consonant-final nouns, speaker BM produces

\begin{tabular}{|c|c|c|c|}
\hline megel-yal & $\sim$ megel-o & $\sim$ megel-o-yal & 'men' \\
\hline & irbið-o & irbið-o-yal & 'needles' \\
\hline dik-yal-ki & $\sim$ diiy-o & $\sim$ diiy-o-yal & 'roosters' \\
\hline hambal-yal-ki & $\sim$ hambal-o & $\sim$ hambal-o-yal-ki & ‘leaves’ \\
\hline basal-yal & $\sim$ basal-o & basal-o-yal & 'onions' \\
\hline & $\sim$ hawuuy-o & $\sim$ hawuuy-o-yal & 'corn (pl.)' \\
\hline laðak-yal-ki & $\sim$ haðау-о & $\sim$ haðay-o-yal & 'ropes' \\
\hline & $\sim$ ilbaa $\beta-o$ & $\sim$ ilbaa $\beta$-o-yal & 'doors' \\
\hline yal & beleð-o & beleð-o-yal & 'cities' \\
\hline 1-ki & $\sim$ nal-o & $\sim$ nal-o-yal-ki & 'lights' \\
\hline val-ki & $\sim$ barið-o & barið-o-yal & 'rice (pl.)' \\
\hline al-ki & $\sim \operatorname{roo} \beta-o$ & $\sim \operatorname{roo} \beta$-o-yal & 'rains' \\
\hline -yal & $\sim$ moos-o & $\sim$ moos-o-yal & 'bananas' \\
\hline & $\sim$ buuy-o & $\sim$ buuy-o-yal-ki & 'books' \\
\hline k k-yal & 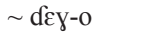 & $\sim$ def-o-yal & 'ears' \\
\hline
\end{tabular}
three different forms, as shown in (6).

(6)

\begin{abstract}
${ }^{6}$ Speaker BM often puts the determiner $-k i$ 'the' or - $k a \eta$ 'this' on the plural form and hesitates to pronounce some words without a determiner; at present I do not have an explanation for this phenomenon. Maay exhibits variant of 'gender polarity' (found in many Cushitic languages) in which all plural nouns are masculine regardless of the gender of the singular; therefore if a determiner is used with a plural noun, it will belong to the masculine $k$ set (e.g., $-k i,-k a \eta$ ) rather than the feminine $t$ set (e.g., -ti,-tan); see Paster (2007) for discussion. The masculine plural pattern is uniform for the ten Maay speakers that I consulted, though speakers differ in their analysis of the gender of some singular nouns (Paster, 2018). My research their behavior with respect to plural marking.
\end{abstract}


(6)

\begin{tabular}{|c|c|c|c|}
\hline $\begin{array}{l}\text { kob-yal } \\
\text { gect-yal }\end{array}$ & $\begin{array}{l}\sim \text { koß-o } \\
\sim \text { gecठ-о }\end{array}$ & $\begin{array}{l}\sim \text { koß-o-yal } \\
\sim \text { gecठ-o- }\end{array}$ & $\begin{array}{l}\text { 'cups' } \\
\text { 'trees' }\end{array}$ \\
\hline & $\sim$ sum-o- & $\begin{aligned} & \text { yal-ki } \\
& \sim \text { sum-o-yal- }\end{aligned}$ & 'poisons' \\
\hline & yan & kay & \\
\hline don-yal-ki & $\sim$ doom-o & $\sim$ doom-o-yal & ‘boats' \\
\hline dinan-yal & $\sim$ dinaam-o & $\begin{array}{l}\sim \text { dinaam-o- } \\
\text { yal }\end{array}$ & 'babies' \\
\hline 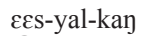 & $\sim \varepsilon \varepsilon s-\mathrm{o}$ & 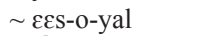 & 'grasses' \\
\hline dzer-yal-ki & $\begin{array}{l}\sim \text { dुeer-o- } \\
\text { yi }\end{array}$ & $\sim \overline{\text { dzeer-o-yal }}$ & 'hippos' \\
\hline kuraas-yal-ki & $\sim$ kuraas-o & $\sim$ kuraas-o-yal-ki & ‘sofas' \\
\hline ber-yal & $\sim$ beer-o & $\begin{array}{l}\sim \text { beer-o-yal- } \\
\text { ki }\end{array}$ & 'gardens' \\
\hline & $\sim$ luy-o & luy-o-yal-ki & 'feet' \\
\hline & $\sim \widetilde{\text { dzið }}$ & $\sim$ dzio-o-yal & \\
\hline & $\sim$ gaam-o & $\sim$ gaam-o-yal & ‘jaws’ \\
\hline
\end{tabular}

However, for some nouns this speaker rejects the $-O$ form but gives both the -yal and -o-yal forms, as shown in (7). ${ }^{7}$ In some cases, BM explicitly rejected forms that $\mathrm{OM}$ had produced (e.g., af-o, which was in fact the first form that $\mathrm{OM}$ volunteered for 'mouths').

$\begin{array}{llll}\text { af-yal } & * \text { af-o } & \sim \text { af-o-yal-kay } & \text { 'mouths' } \\ \text { dep-yal-ki } & * \text { d } \varepsilon \beta-o & \sim \text { d } \beta \beta-\text { o-yal-ki } & \text { 'fires' } \\ \text { loos-yal-ki } & * \text { loos-o } & \sim \text { loos-o-yal-ki } & \text { 'peanuts' }\end{array}$

A possible explanation for why these nouns have an -o-yal form is that BM's grammar includes -oyal as a single suffix alongside $-o$ and $-y a l$. Otherwise it is puzzling why these nouns that cannot take - $O$ can still take $-o-y a l$, given that nouns can end in $-o$, as amply attested above.

Turning now to speaker AM, usually only the $-y a l$ form is given for vowel-final stems, as shown in (8).

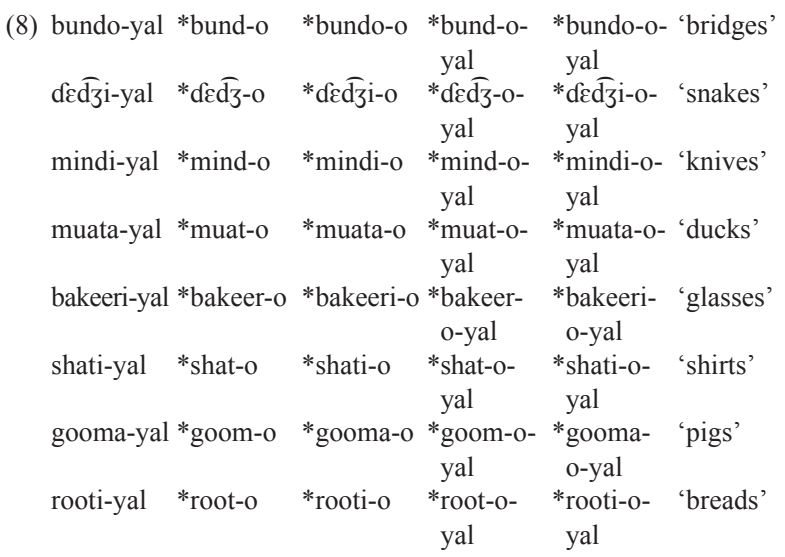

This suggests that the -o suffix is phonologically restricted to consonant-final roots for AM (as for speaker $\mathrm{OM}$ ). AM never gives a vowel-final noun with the $-o$

\footnotetext{
${ }^{7}$ A reviewer inquired about longitudinal consistency in speakers' judgments that certain forms were ungrammatical. Except for forms with a question mark (which I call 'dispreferred'), the examples in this paper (both the grammatical forms and the starred, rejected forms) reflect consistent judgments/utterances across sessions.
}

suffix attached after the root-final vowel in my dataset. In a very few exceptional cases, AM replaces the final vowel with $-o$, as seen in (9).

(9) bakaile- $\sim$ bakail-o *bakaile-o *bakail-o- *bakaile- 'rabbits' $\begin{array}{llllll}\text { yal } & & \text { yal } & \text { o-yal } \\ \text { maða-yal } & \sim \text { mað-o } & * \text { maða-o } & \begin{array}{c}\text { *mað-o- } \\ \text { yal }\end{array} & \begin{array}{c}\text { *maða-o- 'heads' } \\ \text { yal }\end{array} & \\ \text { raka-yal } & \text { ?rak-o } & * \text { *raka-o } & \begin{array}{c}\text { *rak-o- } \\ \text { yal }\end{array} & \begin{array}{c}\text { *raka-o- } \\ \text { yal }\end{array} & \text { 'frogs' }\end{array}$

We observed a similar phenomenon for speaker BM, but note that the specific roots having these allomorphs differ from the roots that BM treated this way (and, in fact, BM explicitly rejects the - $O$ forms for all three of the nouns in (9)). Also unlike BM, AM rejects the -o-yal forms of the nouns in (9). My analysis is that for AM these three nouns have lexically listed (irregular) plurals alongside the regular -yal form (since an analysis with root allomorphs in free variation, like the one proposed for speaker BM, would fail to explain why AM's nouns in (9) lack an -o-yal form).

As seen in (10), speaker AM gives only two forms for most consonant-final stems, rejecting the -o-yal forms of these nouns (which OM uniformly accepted, and which BM also accepted in most cases, as discussed above).

\begin{tabular}{|c|c|c|c|c|}
\hline \multirow[t]{18}{*}{ (10) } & \multirow{18}{*}{$\begin{array}{l}\text { los-yal } \\
\text { eey-yal } \\
\text { goryan-yal } \\
\text { kop-yal } \\
\text { ees-yal } \\
\text { af-yal } \\
\text { dzer-yal } \\
\text { ber-yal } \\
\text { kal-yal } \\
\text { dzit-yal } \\
\text { det-yal } \\
\text { mos-yal } \\
\text { diik-yal } \\
\text { nal-yal } \\
\text { sun-yal } \\
\text { mukulal-yal } \\
\text { kuras-yal } \\
\text { basal-yal }\end{array}$} & $\sim$ loos-o & *loos-o-yal & 'peanuts' \\
\hline & & $\sim$ eey-o & *eey-o-yal & 'dogs' \\
\hline & & $\sim$ goryaam-o & *goryaam-o-yal & 'stomach worms' \\
\hline & & $\sim$ ko $\beta-\mathrm{o}$ & *koß-o-yal & ‘cups’' \\
\hline & & $\sim$ ees-o & *ees-o-yal & 'grasses' \\
\hline & & $\sim$ af-o & *af-o-yal & 'mouths' \\
\hline & & $\sim \widehat{\mathrm{d} z e e r-o}$ & * बิzeer-o-yal & 'hippos’' \\
\hline & & $\sim$ beer-o & *beer-o-yal & 'gardens'/'livers' \\
\hline & & $\sim$ kaal-o & *kaal-o-yal & ‘spoons’ \\
\hline & & 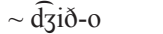 & *d̄ið-o-yal & 'roads' \\
\hline & & $\sim \mathrm{d} \varepsilon ð-\mathrm{o}$ & *deð-o-yal & 'peoples' \\
\hline & & $\sim$ moos-o & *moos-o-yal & 'bananas' \\
\hline & & $\sim$ diiy-o & *diiz-o-yal & 'roosters' \\
\hline & & $\sim$ nal-o & *nal-o-yal & 'lights’ \\
\hline & & $\sim$ suum-o & *suum-o-yal & 'belts' \\
\hline & & $\sim$ mukulaal-o & *mukulaal-o-yal & 'cats' \\
\hline & & $\sim$ kuraas-o & *kuraas-o-yal & 'chairs' \\
\hline & & $\sim$ basal-o & *basal-o-yal & 'onions' \\
\hline
\end{tabular}

AM does, however, give all three forms for some consonant-final nouns, as seen in (11).

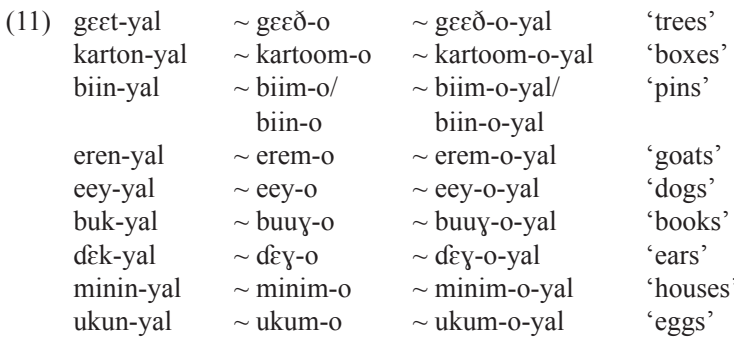


For other nouns, AM accepts the -o-yal form but disprefers it (in some cases the form is volunteered on one occasion but later rejected, or vice versa), as seen in (12).

$\begin{array}{llll}\text { mas-yal } & \sim \text { mas-o } & \text { ?mas-o-yal } & \text { 'snake' } \\ \text { sanduk-yal } & \sim \text { sanduuy-o } & \text { ?sanduur-o-yal } & \text { 'drawers' } \\ \text { hindik-yal } & \sim \text { hindiy-o } & \text { ?hindiy-o-yal } & \text { 'stars' } \\ \text { mis-yal } & \sim \text { miis-o } & \text { ?miis-o-yal } & \text { 'tables' }\end{array}$

The -o-yal combination is thus clearly somewhat limited for speaker AM. A possible explanation is that it may be analyzed as a single suffix -oyal (as I suggested earlier for speaker BM) that is lexically restricted (in addition to being phonologically restricted, explaining why it never occurs with a vowel-final root).

For two consonant-final nouns, as shown in (13), AM rejects the $-o$ form in favor of the -yal form. For these two nouns, there is also no -o-yal form. Note that AM's rejection of * suum-o-yal contradicts BM, who did produce an -o-yal plural for this noun as cited above.

(13) amel-yal *ameel-o *ameel-o-yal 'mugs'

sun-yal *suum-o *suum-o-yal 'poisons' (cf. 'belts' in (10))

These nouns may have lexically listed plurals for AM that end in $-y a l$ and block the formation of the $-o$ form. The lack of an - $o$ form for 'poisons' may also relate to the form of 'belts' cited above in (10). ${ }^{8}$

Another speaker, HJ, is relatively permissive with multiple plural marking, allowing it for most nouns that have an - $O$ form, as seen in (14).

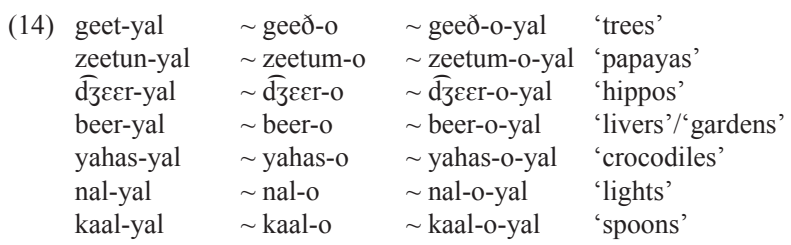

Three exceptions were observed where an - $o$ form is accepted but the -o-yal form is rejected; these are given in (15). Note that these rejected forms were accepted by other speakers: the -o-yal form for 'tables' was accepted by $\mathrm{OM}$ and marginally accepted (dispreferred) by AM; the $-o-y a l$ form for 'fires' was accepted by BM, and the -o-yal form was accepted by both BM and AM.

\begin{tabular}{|c|c|c|c|}
\hline (15) & $\begin{array}{l}\text { miis-yal } \\
\text { dep-yal } \\
\text { buug-yal }\end{array}$ & $\begin{array}{l}\sim \text { miis-o } \\
\sim \text { de } \beta-\mathrm{o} \\
\sim \text { buuy-o }\end{array}$ & $\begin{array}{l}*_{\text {miis-o-yal }} \\
* \mathrm{~d} \varepsilon \beta-\mathrm{-o}-\mathrm{yal} \\
* \text { buuy-o-yal }\end{array}$ \\
\hline
\end{tabular}

\footnotetext{
8 'Poison' and 'belt' are homophones for this speaker, and he produced their plurals at the same point in the elicitation, making a point of differentiating the two by saying that suumo could only mean 'belts', not 'poisons'. Therefore it may be that a conscious desire to differentiate these two nouns was responsible for the rejection of the - $o$ form for 'poisons'.
}

Speaker HJ states that -o-yal forms are semantically distinct from the other two (though not in an identifiable, consistent way, as discussed by Paster, 2013), so I hypothesize that the three rejected forms in (15) may be possible but were rejected due to my failure during elicitation to provide an appropriate real-world context for their use. I will therefore not propose a separate -oyal suffix (or lexically listed plurals ending in /oyal/) for $\mathrm{HJ}$ as I did for other speakers for whom some -o-yal plurals were rejected.

In one case, cited in (16), HJ produces a form with $-y a l-o$ - the only such example produced by any of the speakers in this study.

(16) ey-yal $\sim$ ey-o $\sim$ ey-o-yal $\sim$ ey-yal-o 'dogs'

The judgment was consistent across sessions for this speaker, but he never produced any other nouns with this pattern. I tentatively conclude that eyyalo is a lexically listed form.

Example (17) demonstrates that for speaker HJ, the existence of a -yal form is not necessary for the -o-yal form to be accepted.

$$
\text { *kop-yal } \quad \text { koß-o } \quad \sim \text { koß-o-yal 'shoes' }
$$

As demonstrated in (18), for HJ, the presence of an $-O$ form does seem to be a necessity in order for the -o-yal form to be accepted (just as for speaker AM, but not for BM).

\begin{tabular}{|c|c|c|c|}
\hline$\varepsilon \varepsilon s-y a l$ & 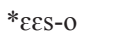 & 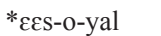 & 'grasses' \\
\hline af-yal & *af-o & *af-o-yal & 'mouths' \\
\hline los-yal & *los-o & *los-o-yal & 'peanuts' \\
\hline moos-yal & *moos-o & *moos-o-yal & 'bananas' \\
\hline oof-yal & $*$ too $\int-o$ & *toof-o-yal & 'flashlights' \\
\hline aras yo & *makas-o & *makas-o-yal & ‘scissors’ \\
\hline
\end{tabular}

The examples in (18) are representative of HJ's data in that he produced no nouns with an -o-yal form that did not also have an -o form. This suggests that unlike speakers $\mathrm{AM}$ and $\mathrm{BM}$ discussed earlier, HJ does not have a distinct -oyal suffix.

Speaker LJ, another male speaker, exhibits yet a fifth different pattern. For this speaker, many vowel-final nouns have both $-y a l$ forms and forms where - $O$ appears to replace the stem-final vowel, as shown in (19).

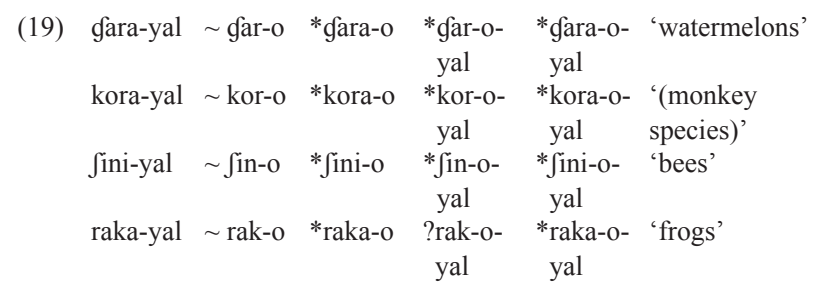

\footnotetext{
${ }^{9}$ Since this is apparently the only noun that behaves this way, my analysis is that the -yal form is avoided for this noun in order to differentiate it from kopyal meaning 'cups', much like speaker AM did with the nouns 'belt' and 'poison' referenced in footnote 8 . HJ explicitly contrasted the two nouns when he gave the form for 'shoes'.
} 
Comparable forms produced by speaker BM were analyzed as resulting from some vowel-final nouns having two underlying forms in free variation (one with the final vowel and one without); I will adopt the same analysis for LJ's nouns in (19). For LJ, the -o-yal form is either rejected or marginal for all of the nouns in (19).

There are also some vowel-final nouns that have only a -yal form for this speaker, as shown in (20). Note that *mað-o 'heads', rejected by LJ (and also by BM, as was shown earlier), was accepted by speaker AM.

$$
\begin{aligned}
& \text { (20) embe-yal *emb-o *embe-o *emb-o-yal *embe-o- 'mangos' } \\
& \text { maða-yal *mað-o *maða-o *mað-o-yal *maða-o- 'heads' } \\
& \text { kofia-yal *kofi-o *kofia-o *kofi-o-yal *kofia-o- 'hats' } \\
& \text { yal }
\end{aligned}
$$

A small number of LJ's nouns have a -yal form and an additional, unusual form where $-o$ attaches after the final vowel, as shown in (21). Such forms are not attested for any other speaker in the group.
(21) bakeri- *baker-o bakeri-o *baker- *bakeri- 'cup'

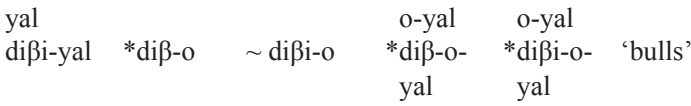

One vowel-final noun has only the - $o$ form, while the $-y a l$ form is rejected, as shown in (22).

(22) *woßi-yal *wo $\beta$-o woßi-o *woß-o-yal *woßi-o-yal 'rivers'

Another example of an $i$-final noun, shown in (23), has three plurals including an -o-yal form without deletion of the root-final vowel - the only example of its type in my data from all speakers.

(23) mindi-yal *mind-o $\sim$ mindi-o *mind-o- $\sim$ mindi- 'knives' yal o-yal

Examples (19) and (21)-(23) represent all elicited nouns ending in $-i$; their behavior suggests that $\mathrm{LJ}$ treats $i$-final stems as consonant-final.

For LJ, one vowel-final noun (24) has both $-o$ and -o-yal plurals with the stem-final vowel missing. This noun can be analyzed like the ones in (19) which have two underlying forms in free variation.

(24) waraa $\beta$ a- $\sim$ waraa $\beta$-o *waraa $\beta$-o $\sim$ waraa $\beta$ - *waraa $\beta$ - 'hyenas' yal o-yal o-yal

The difference between (19) and (24) will follow from the fact that some of LJ's consonant-final nouns have plurals ending in /oyal/ (whether they are lexically listed plural forms or nouns that a restricted -oyal suffix can attach to); see below.

Most consonant-final roots can take either $-y a l$ or $-o$ but not -o-yal for $\mathrm{LJ}$, as shown in (25). LJ is unusual in this regard, since many of the rejected -o-yal forms in (25) were accepted by other speakers (of the 24 rejected forms in (25), at least one other speaker produced an -o-yal forms for 17 of these nouns, and the remaining seven for the most part reflect a lack of comparative data from other speakers).

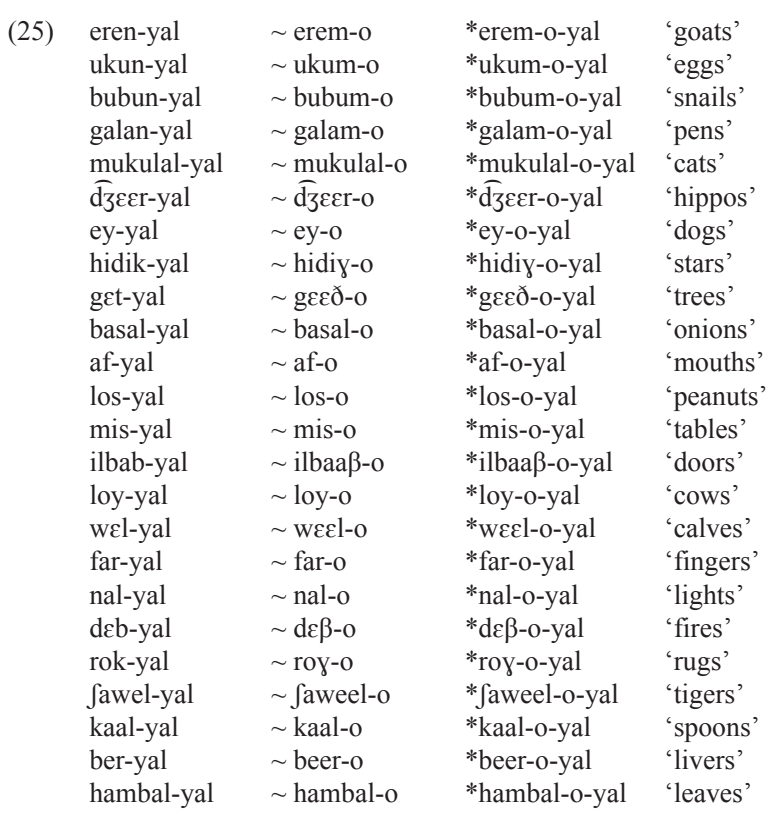

One noun with this pattern, given in (26), has a -yal form and two - $o$ forms for LJ, reflecting variability in the final consonant.

(26) didin-yal $\begin{array}{r}\sim \text { didin-o/ } \\ \text { didim-o }\end{array} \quad \begin{gathered}* \text { didim-o-yal/ } \\ \text { didino-yal }\end{gathered} \quad$ 'turtles'

Generally for all speakers, as can be seen throughout the earlier examples, nasal-final roots exhibit an alternation whereby the nasal surfaces as [ $\mathrm{y}$ ] in word-final position, as [n] before -yal (indicated as $<\mathrm{n}>$ in our transcription system), and as $[\mathrm{m}]$ before the $-o$ suffix (see Paster, 2007; Comfort and Paster, 2009; and Paster, 2010, for more details). Speaker LJ has the same pattern, but the noun in (26) optionally ends in [n] across the board, constituting an exception to the nasal place-changing rules.

A number of other consonant-final nouns have three plural forms for speaker LJ, as seen in (27).

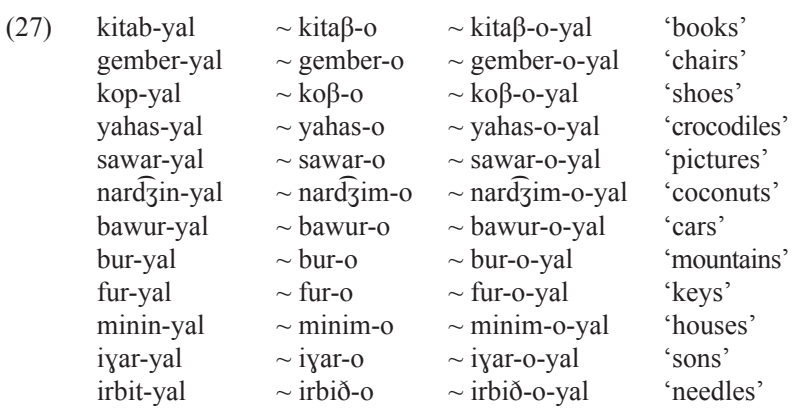

Because the nouns in (27) have plurals ending in / oyal/ while the ones in (25) do not - but both types have $-o$ plurals - we must conclude that the ability to 
form an /oyal/ plural is a lexical property of roots. We may further conclude that /oyal/ plurals for this speaker are not formed by adding -yal to a noun already bearing - $o$ (as we assumed for $\mathrm{OM}$ and $\mathrm{HJ}$ ) since the lack of /oyal/ forms in (25) would mean that the regular -o plurals of these nouns would have to be marked as not accepting further affixation of -yal. (Note that the roots could not be marked as not accepting -yal since all of the nouns in (25) have -yal plurals.) Thus, we conclude that LJ has a suffix -oyal whose distribution is lexically restricted. Recall that the same conclusion was made for BM, though with different reasoning (in the case of BM we posited -oyal because she produced some nouns with /oyal/ plurals but rejected the corresponding - $o$ plurals, suggesting that the /oyal/ forms were not formed by adding -yal to a base already containing $-o$ ). An alternative to the -oyal suffix is to posit that the forms with /oyal/ plurals (for LJ and/or for BM) are lexically listed as full plural words ending in /oyal/; I do not have data that can distinguish between these two analyses for either speaker.

An interesting minimal pair arises for speaker LJ between 'belts' and 'poisons', shown in (28). The nouns in isolation are homophones, but they do not share any plural forms: 'belts' can take -yal or -o-yal but not $-o$, while 'poisons' takes $-o$ but neither of the other forms.

$$
\begin{array}{llll}
\text { sun-yal } & * \text { sum-o } & \sim \text { sum-o-yal } & \text { 'belts' } \\
\text { *sun-yal } & \text { sum-o } & * \text { sum-o-yal } & \text { 'poisons' }
\end{array}
$$

Comparing (28) with the examples from speaker AM cited earlier in (10) and (13) for the same nouns, we see that the two speakers' forms directly contradict each other. Speaker AM had both -yal and -o forms for 'belts' but only -yal for 'poisons', a form which LJ explicitly rejects in (28). ${ }^{10}$

For LJ, as shown in (29), one consonant-final noun has only a -yal form.

$$
\text { kop-yal *koß-o *koß-o-yal 'cups' }
$$

This anomaly may again be due to an effort to distinguish this noun from a homophonous one, namely 'shoes' (cited in (27)), but in this case the other noun has all three plural forms whereas 'cups' is restricted to only one plural form. ${ }^{11}$

\footnotetext{
${ }^{10}$ One benefit of group fieldwork in a community is the opportunity to ask speakers to discuss idiolectal variation with each other. In this case, AM and LJ discussed the forms and agreed to disagree. The fact that speakers distinguish these nouns in different ways suggests that there is a drive to distinguish the plural forms of different nouns, but when the speech community supplies conflicting data on how to do this, the task is left to individual innovation with sometimes disparate results.

${ }^{11}$ Another possible explanation for this form may relate to the fact that kop is borrowed; however, the language contains many borrowed nouns as can be seen throughout the examples in the paper, so being a loanword does not uniquely distinguish this noun. There may be an effect of the recency and/or source of the borrowing.
}

LJ produces one consonant-final noun with an unusual pattern shown in (30) where there is no -yal form but there are $-o$ and $-o-y a l$ forms. ${ }^{12}$

$$
\text { *dek-yal } \quad \text { d } \varepsilon \gamma-o \quad \sim \text { d } \varepsilon \gamma-o-y a l \quad \text { 'ears' }
$$

And finally for speaker LJ, one consonant-final noun, shown in (31), lacks both the -yal and -o-yal forms.

$$
\text { *basbas-yal basbas-o *basbas-o-yal 'peppers' }
$$

I analyze this as a lexically listed plural form, but it is also possible that the speaker may be analyzing this noun as reduplicated (even though it is not transparently reduplicated from an attested noun, and there does not seem to be a productive noun reduplication process). As reported by Comfort and Paster, 2009, there is some complementarity between adjective reduplication and plural marking within DPs in Maay. The complex relationships among reduplication, other pluralization strategies, and numerals in the Maay DP are the subject of ongoing research.

Table 2 provides a summary of the individual patterns discussed above.

To summarize the findings in this section, we may observe the following. First, we have seen that even for individuals, the patterns of plural marking are very complex and exhibit some arbitrariness. However, an empirically adequate analysis is nonetheless available for each speaker's patterns. The analyses range in complexity; on one end of the scale we are able to state a phonologicallybased distribution for OM where vowel-final stems take the -yal suffix, while consonant-final stems can take $-o$, $-y a l$, or a combination of the two with no exceptions. Other speakers exhibit variations on this pattern with varying degrees of complexity; the analyses of these patterns involved lexical listing of plural forms and lexically specified blocking.

An important conclusion here is that if all of the speakers' plural forms were pooled together, the resulting dataset would be incoherent and in many cases outright self-contradictory. We have seen some striking examples of contradictory data, especially in cases where one speaker explicitly and emphatically ruled out a form that another speaker pronounced and accepted with just as much confidence. An analysis of variation at the community level would not be at all useful in understanding such forms. To say that form A is used some percentage of the time $v s$. form B would completely obscure the fact that individuals have absolute judgments; these are matters of grammaticality that have no possible resolution at the level of the community but are easily described at the level of the individual.

\footnotetext{
12 This may be due to semantics, since LJ differentiates the plural forms semantically, with the $-o$ suffix being associated with a smaller number than -yal. If the speaker interpreted the English prompt 'ears' as referring to 'a pair of ears', then it would not make sense to use the -yal form, which would simply be a large number of individual ears; once - $o$ is attached indicating 'ears' (perhaps a pair of ears), then the -o-yal form could mean 'many people's (pairs of) ears'.
} 
Table 2: Summary of five speakers' plural formation systems.

\begin{tabular}{|c|c|c|c|c|c|}
\hline & OM & BM & $\mathbf{A M}$ & HJ & LJ \\
\hline -o occurs on C-final stems & $\mathrm{x}$ & $\mathrm{x}$ & $\mathrm{x}$ & $\mathrm{x}$ & $\mathrm{x}^{\mathrm{i}}$ \\
\hline -yal occurs on any stem (even if already plural) & $\mathrm{x}$ & $\mathrm{x}$ & & $\mathrm{x}$ & \\
\hline -yal occurs on any [-plural] stem & & & $\mathrm{x}$ & & $\mathrm{x}$ \\
\hline -oyal occurs on C-final stems, lexically restricted $\mathrm{d}^{\mathrm{ii}}$ & & $\mathrm{x}$ & $\mathrm{x}$ & & $x^{i}$ \\
\hline some nouns have listed plurals with $/ \mathrm{o} /$ in place of final $\mathrm{V}$ & & & $\mathrm{x}$ & & $x^{i}$ \\
\hline some listed -yal plurals block the -o form & & & $\mathrm{x}$ & & \\
\hline some V-final stems vary with a C-final allomorph & & $\mathrm{x}$ & & & $x^{i}$ \\
\hline
\end{tabular}

${ }^{\mathrm{i}} \mathrm{LJ}$ treats /i/-final stems as C-final (see text).

ii Alternatively, some nouns have listed plurals ending in /oyal/ (see text for discussion).

An analysis of the patterns in each individual's grammar would be impossible if all tokens and ungrammaticality judgments were pooled across speakers; for example, to say that mindi-o is a variant of 'knives' (because LJ uses it) would yield an incorrect analysis of BM's grammar since she categorically rejects this form and others like it (her representation of the - $o$ suffix prohibits it, apparently without exception, from occurring post-vocalically). It is not even clear what it might mean to pool cross-speaker data when the 'data' include both (grammatical) utterances and negative grammaticality judgments, since in an aggregate dataset a form like mindi-o would be simultaneously a 'variant' and an 'ungrammatical form'.

In the next section, I turn to a description of variation in a set of vowel lengthening/shortening alternations. As we will see, a similar pattern emerges as with the distribution of plural suffixes: each individual has a describable phonological system, but pooling the data across speakers would yield an unanalyzable dataset.

\section{VARIATION IN VOWEL LENGTH ALTERNATIONS}

I begin by presenting all of the speakers' data at once, and will then explain how each individual's data make sense despite the apparent chaos of the dataset as a whole. The data are provided in (32). We can see that for each noun, speakers may exhibit closed syllable shortening, open syllable lengthening, minimal word lengthening, and/or combinations of these. (SNA indicates that the noun has a short vowel in its citation form and the vowel length is non-alternating. LNA indicates that the vowel is long in the citation form, and non-alternating. SA indicates a short vowel in the citation form, but with alternating length, and LA indicates that the vowel is long in the citation form, and that it alternates. These designations do not necessarily indicate the vowel length in the underlying form of these nouns, as will be important to the analysis.)

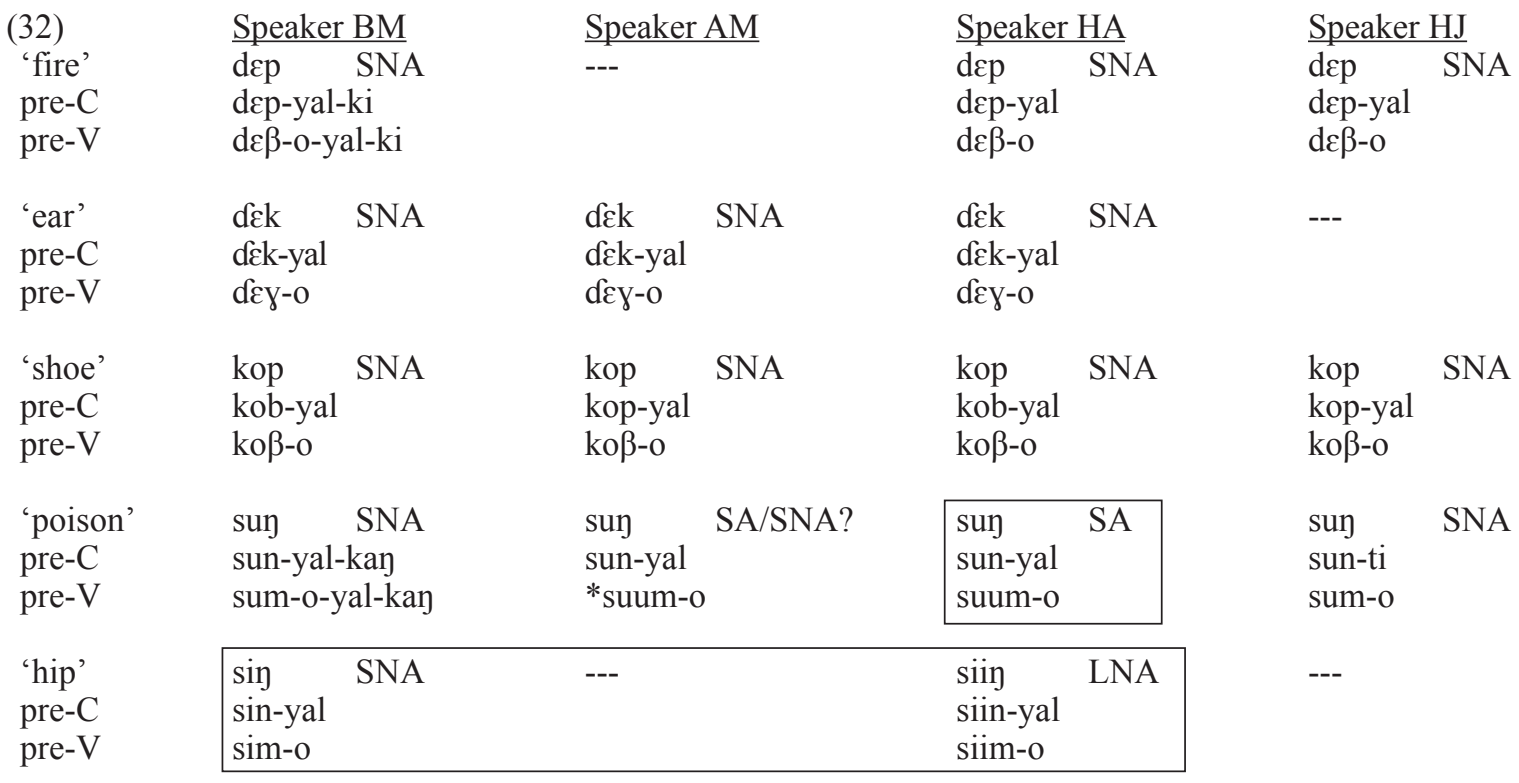




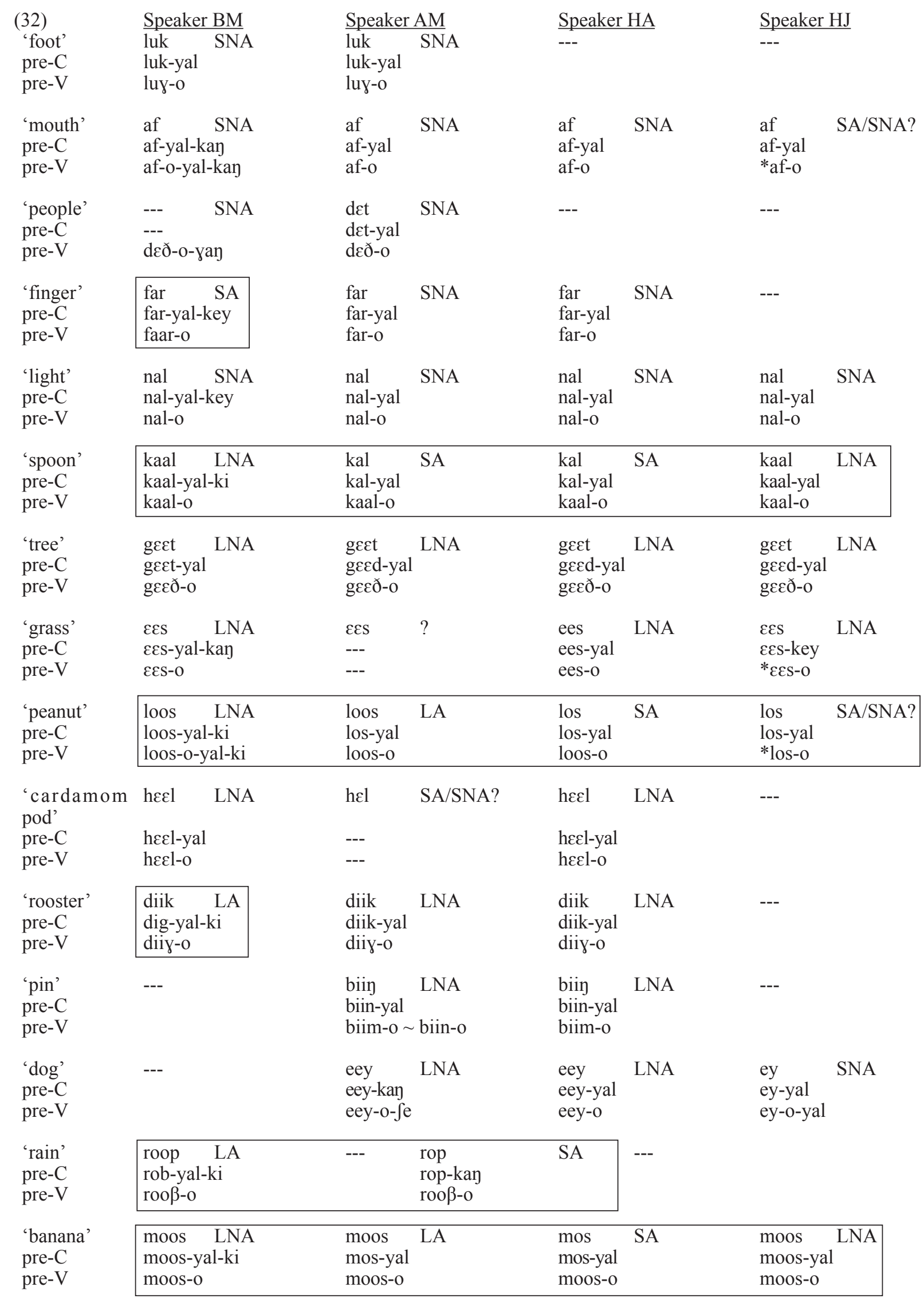




\begin{tabular}{|c|c|c|c|}
\hline Speaker BM & Speaker AM & Speaker HA & Speaker HJ \\
\hline-- & $\begin{array}{ll}\text { suuk } & \text { LA } \\
\text { suk-yal } & \\
\text { suuy-o } & \end{array}$ & $\begin{array}{ll}\text { suk } & \text { SA } \\
\text { suk-yal } & \\
\text { suuy-o } & \end{array}$ & --- \\
\hline
\end{tabular}

\begin{tabular}{|c|c|c|c|c|c|c|c|}
\hline $\begin{array}{l}\text { ‘liver’ } \\
\text { pre-C } \\
\text { pre-V }\end{array}$ & --- & $\begin{array}{l}\text { ber } \\
\text { ber-kay } \\
\text { beer-o }\end{array}$ & SA & --- & & $\begin{array}{l}\text { beer } \\
\text { beer-yal } \\
\text { beer-o }\end{array}$ & LNA \\
\hline $\begin{array}{l}\text { 'garden’ } \\
\text { pre-C } \\
\text { pre-V }\end{array}$ & $\begin{array}{ll}\text { ber } & \text { SA } \\
\text { ber-yal } & \\
\text { beer-o } & \end{array}$ & $\begin{array}{l}\text { ber } \\
\text { ber-tan } \\
\text { beer-o }\end{array}$ & SA & $\begin{array}{l}\text { beer } \\
\text { beer-yal } \\
\text { beer-o }\end{array}$ & LNA & $\begin{array}{l}\text { beer } \\
\text { beer-yal } \\
\text { beer-o }\end{array}$ & LNA \\
\hline $\begin{array}{l}\text { ‘hippo’ } \\
\text { pre-C } \\
\text { pre-V }\end{array}$ & $\begin{array}{l}\text { dzer SA } \\
\text { dzer-yal-ki } \\
\text { dzeer-o-yi }\end{array}$ & $\begin{array}{l}\text { dzer } \\
\text { dzer-yal } \\
\text { dzeer-o }\end{array}$ & SA & $\begin{array}{l}\text { dzeer } \\
\text { dzeer-yal } \\
\text { dzeer-o }\end{array}$ & LNA & $\begin{array}{l}\text { dzeer } \\
\text { dzeer-yal } \\
\text { dzeer-o }\end{array}$ & LNA \\
\hline $\begin{array}{l}\text { 'table' } \\
\text { pre-C } \\
\text { pre-V }\end{array}$ & --- & $\begin{array}{l}\text { mis } \\
\text { mis-yal } \\
\text { miis-o }\end{array}$ & SA & $\begin{array}{l}\text { miis } \\
\text { miis-yal } \\
\text { miis-o }\end{array}$ & LNA & $\begin{array}{l}\text { miis } \\
\text { miis-key } \\
\text { miis-o }\end{array}$ & LNA \\
\hline $\begin{array}{l}\text { ‘book’ } \\
\text { pre-C } \\
\text { pre-V }\end{array}$ & $\begin{array}{l}\text { buuk LA } \\
\text { buk-yal-ki } \\
\text { buuy-o }\end{array}$ & $\begin{array}{l}\text { buk } \\
\text { buk-yal } \\
\text { buuy-o }\end{array}$ & SA & $\begin{array}{l}\text { buk } \\
\text { buk-yal } \\
\text { buuy-o }\end{array}$ & SA & $\begin{array}{l}\text { buuk } \\
\text { buug-yal } \\
\text { buuy-o }\end{array}$ & LNA \\
\hline $\begin{array}{l}\text { 'belt' } \\
\text { pre-C } \\
\text { pre-V }\end{array}$ & --- & $\begin{array}{l}\text { sun } \\
\text { sun-yal } \\
\text { suum-o }\end{array}$ & SA & $\begin{array}{l}\text { suy } \\
\text { sun-yal } \\
\text { suum-o }\end{array}$ & SA & $\begin{array}{l}\text { suy } \\
\text { sun-yal } \\
\text { sum-o }\end{array}$ & SNA \\
\hline
\end{tabular}

The examples in (32) include only nouns that are monosyllabic and that were elicited from enough speakers to allow for a comparison. Each noun is presented in isolation, with a consonant-initial suffix, and with a vowel-initial suffix. I am using the plural suffixes to illustrate since these will be familiar from the preceding section, but the available data indicate that, for each of these speakers, the length of the root vowel in the -yal plural form is the same as with any other consonant-initial suffix. I assume the $-o$ forms to be representative of forms with any vowel-initial suffix, but I have not found other productive vowel-initial noun suffixes.

In comparing the forms in (32), we see that some nouns such as 'fire' and 'ear' are consistent across speakers. Boxed forms, however, indicate that different speakers treat those nouns differently. For example, 'poison' is short and non-alternating for speakers BM and $\mathrm{HJ}$, and possibly for AM (we cannot know for sure because he rejects the $-o$ form), but the same noun is short and alternating for speaker HA. The noun 'spoon' has a box across all speakers because two of them treat it as long and non-alternating while two treat it as short and alternating. The noun 'peanut' is striking since the four speakers treat it in three or even four different ways; there are also three different patterns for 'banana' and 'book'.

I will now proceed to show that we can analyze each individual's data with a set of underlying forms and rules that is consistent for each speaker (but differs across speakers), and that a clear and straightforward analysis is available for each person's grammar. One important note is that the analysis provided for each speaker has been checked against all additional examples in my notes; although I have only presented monosyllabic nouns for which I had a significant number of cross-speaker examples, the analyses below are consistent with all available data for each speaker, not only the data cited above.

Beginning with speaker BM, we can assume underlying forms where nouns I have designated as 'SNA' and 'SA' (e.g., /dcp/ 'fire' and /far/ 'finger', respectively) have short vowels while 'LNA' and 'LA' nouns (e.g., / kaal/ 'spoon' and /buuk/ 'book') have long vowels. The system can then be analyzed with one shortening rule and one lengthening rule. The shortening rule, given in (33), shortens vowels before a non-coronal consonant plus a consonant-initial suffix.

$$
\begin{aligned}
& \text { Shortening (BM) } \\
& \mathrm{V} \rightarrow[\text {-long }] / \text { - } \\
& \quad \text {-coronal }]
\end{aligned}
$$

This accounts for stem alternations such as buuk $b u k$, while the [-coronal] restriction prevents shortening from incorrectly applying to coronal-final stems like kaal.

BM's lengthening rule, given in (34), lengthens nonhigh vowels before a non-lateral sonorant consonant plus a vowel-initial suffix. 


$$
\begin{aligned}
& \text { Lengthening (BM) } \\
& \underset{\substack{\mathrm{V} \rightarrow[\text { high }]}}{\left[\begin{array}{c}
\text { [+longorant }] \\
{[\text {-lateral }]}
\end{array}\right.}+\mathrm{V}
\end{aligned}
$$

This rule accounts for stem alternations including far $\sim$ faar; the restriction to non-high vowels accounts for the failure of lengthening in stems like suy 'poison', while the [-lateral] restriction prevents lengthening from applying to /l/-final stems such as $n a l$ 'light'. Lengthening and shortening are both necessary since there exist both alternating and non-alternating stems with both long and short vowels. If we posited only a lengthening rule, for example, we would have to reanalyze LA stems like /buuk/ as SA (/buk/), but then we would have to explain why they appear to undergo lengthening in the citation and preconsonant forms while nearly identical nouns (e.g. /luk/ 'foot') do not alternate. If we posited only a shortening rule, the SA stems like /far/ would have to be reanalyzed as LA (/faar/) and we would have to account for why they shorten in isolation and in the pre-consonant environment while LNA stems like /kaal/ do not. ${ }^{13}$ The lengthening and shortening rules are both productive for BM's nouns, including some monosyllabic examples not included here as well as the last vowel of polysyllabic nouns.

Turning to speaker AM, for this speaker again the SNA and SA nouns (e.g., /dغk/ 'ear', /buk/ 'book') have underlying short vowels, while LNA and LA nouns (e.g., /diik/ 'rooster', /loos/ 'peanut') have long vowels. AM also has shortening and lengthening rules, but they are different from BM's rules. AM's shortening rule, given in (35), applies only to back vowels (accounting for the existence of AM's LNA category, which contains only nouns with front vowels).

$$
\begin{aligned}
& \text { Shortening (AM) } \\
& \mathrm{V} \rightarrow[\text {-long }] / \\
& {[+ \text { back }]}
\end{aligned}
$$

In contrast, AM's lengthening rule given in (36), unlike BM's lengthening rule, applies to all vowels rather than only to non-high vowels (so that, e.g., the vowel of / mis/ 'table' does undergo lengthening).

$$
\begin{aligned}
& \text { Lengthening (AM) } \\
& \mathrm{V} \rightarrow[+ \text { long }] / \_\mathrm{C}+\mathrm{V}
\end{aligned}
$$

For AM, as for BM, we need both shortening and lengthening due to the four classes of behavior we observe. If there were only shortening, SA nouns like 'book' would have to be reanalyzed as having underlying long vowels (/buuk/) which shorten in the singular form (buk), but we would have to account for why LA nouns like/suuk/

\footnotetext{
${ }^{13}$ Although all of BM's SA nouns shown in the dataset are $/ \mathrm{r} /$-final, suggesting a shortening rule that applies only to vowels before $/ \mathrm{r} /$, this would not be an accurate generalization about BM since some of her SA nouns not shown here do not end in /r/ (e.g. shawel 'tiger', shawel-yal shaweel-o 'tigers').
}

'market' do not undergo shortening in this context. On the other hand, if there were only lengthening, we would need to reanalyze AM's LA nouns as having underlying short vowels (e.g., /suk/) but would then have to posit an unnatural disjoint context for the lengthening rule (in open syllables, or in closed syllables followed by a word boundary). We would also incorrectly predict that lengthening would apply to SA nouns like buk in the singular. ${ }^{14}$

Speaker HA has a different pattern, and her underlying forms differ significantly from the others'. For HA, as for other speakers, SNA nouns (e.g., /kop/ 'cup') have underlying short vowels and LNA nouns (e.g., /diik/ 'rooster') have underlying long vowels. However, for HA, what I have labeled as the 'SA' nouns have underlying long vowels (as in /kaal/ 'spoon') even though the vowels are short in the citation form. In addition, HA has none of the so-called 'LA' nouns. We can explain both of these facts by considering HA's rules. Her shortening rule applies to back vowels in closed syllables, whether the syllable is closed by a consonant-initial suffix (as with the other speakers) or by a word boundary (which is different from the other speakers). The possibility of the word boundary as a rule trigger is what creates the SA category of nouns for this speaker, since those nouns have underlying long vowels that are shortened in the singular form. HA's shortening rule is given in (37). The [+back] restriction is needed to prevent shortening in words like ees 'grass'.

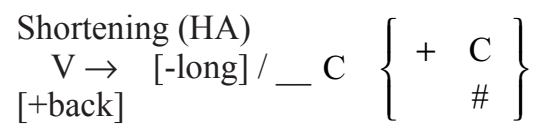

Another difference from the other speakers is that HA has no lengthening rule. Therefore, although no nouns are designated as 'LA' for this speaker, the noun type that is actually missing (relative to the other speakers) is a category where the underlying form has a short vowel that is lengthened in the presence of a vowel-initial suffix.

Finally, speaker $\mathrm{HJ}$ has a radically different pattern from the other three described above. For him, SNA nouns have underlying short vowels, LNA nouns have underlying long vowels, and there are no LA or SA nouns. The explanation for this is that unlike the other speakers, $\mathrm{HJ}$ has no lengthening or shortening rules in his grammar. Speaker OM (not included in the table), whose phonological system is described at length in Paster (2007), has the same pattern as HJ.

To summarize the vowel alternation patterns, we have seen that the speakers differ in terms of the underlying forms of individual roots, the presence of lengthening and/or shortening rules, and the precise formulation of the triggers and targets of their rules.

As with the plural suffix distribution facts discussed in section 3, simply looking at tokens of these nouns as produced by the speech community as a whole in order to understand vowel length alternations in Maay would be

\footnotetext{
${ }^{14}$ An apparent additional problem is that lengthening would apply to SNA nouns. However, under the proposed analysis, AM's SNA must be lexically indicated as not undergoing lengthening anyway.
} 
fruitless. The patterns for a given noun would appear to be random, and the systematicity of the individuals' grammars would be completely obscured. On the other hand, as we have seen, considering the individuals' patterns separately allows each one to be analyzed in a straightforward way.

It should be pointed out that not all approaches acknowledge the possibility of individual speakers of a language having different underlying forms. In fact, advocates of the 'polylectal' approach to variation have assumed that even speakers of identifiably different dialects (not just idiolects) of a language have the same underlying forms and that it is rules/constraints (and hence surface forms) that differ across dialects. This is the approach taken, for example, by Newton in his polylectal grammar of Greek: 'Because dialects arise from an originally more or less uniform language it is possible to show that they can for the most part be described in terms of a common set of underlying forms; variation is introduced by the phonological processes which operate on these forms' (1972, p. 5); see also Honeybone, 2011, for general discussion of the polylectal approach. The Maay data and analysis presented here thus constitute an argument against the polylectal approach since it is not at all clear how one could model the observed interspeaker variation while assuming that speakers of the same language have shared underlying forms without making the claim that, e.g., HA speaks a different language from the other speakers. ${ }^{15}$

\section{CONCLUSION}

In this paper we have seen how interspeaker variation in Maay (morpho)phonology can be understood by considering each speaker's individual grammar, in the domains of plural suffix distribution and vowel length alternations. We discussed for both phenomena how an approach that privileges individuals is superior to one that pools all data and considers the speech community to be the locus of variation and hence the unit of analysis.

The I-language approach may be especially useful in studying languages in refugee communities like the US Somali Bantus, where social upheaval, mixed language histories, and geographic movement have given rise to significant variability and instability in the language. I argue, however, that an I-language approach is the ideal way to study interspeaker variation in any language situation. ${ }^{16}$ The Maay example allowed for a clear demonstration of the superiority of the I-language approach in cases where there is a high degree of interspeaker variation, but if one accepts the present analysis and the rationale

\footnotetext{
${ }^{15}$ Such a statement would be unproblematic for a proponent of the I-language approach, since (as discussed by Hale, 2007, pp. 6-10 and Isac and Reiss, 2008, pp. 14-15) there is no defined scientific analog to the concept of 'a language' in its everyday, sociopolitical sense (e.g., 'the English language'); however, the claim is clearly at odds with the polylectalist goal to find a unified analysis of each 'language'.

${ }^{16}$ I am grateful to an anonymous reviewer for comments that sharpened my thinking regarding the applicability of the I-language approach beyond situations of extreme interspeaker variation.
}

for distinguishing individual grammars, it follows that the I-language model should underlie any analysis of a linguistic system, regardless of the degree of interspeaker variation. Given that the I-language approach offers a built-in explanation for interspeaker variation in terms of distinct mental grammars, no additional mechanisms or alternative modes of analysis are necessary to account for interspeaker variation regardless of how similar or different the individual mental grammars are. Both descriptive and theoretical work will benefit from researchers having clarity about the true object of study - i.e., the mental grammars of individual speakers - that is (or, as I have argued, should be) their focus. Such an approach not only is preferable on principle, but in practical terms it also may yield important insights into otherwise confusing patterns of variation in relatively stable and uniform speech communities that have not previously been subject to this type of analysis.

\section{ACKNOWLEDGEMENTS}

I am enormously grateful to my consultants for their hard work and patience, particularly to Hamadi Jumale, president of the Somali Bantu Community of San Diego organization. I thank the students in my Field Methods class at Pomona College for their contributions to this project. I am also grateful to Charles Reiss, Dave Odden, the audience at the $44^{\text {th }}$ Annual Conference on African Linguistics, and two anonymous reviewers for valuable feedback. This research was funded in part by an Arnold L. and Lois S. Graves grant from the American Council of Learned Societies. All data are from my field notes.

\section{REFERENCES}

Chomsky, N. (1986). Knowledge of Language: Its Nature, Origin, and Use. New York: Praeger.

Comfort, J. \& Paster, M. (2009). Notes on Lower Jubba Maay. In M. Matondo, F. McLaughlin \& E. Potsdam (Eds.), Selected Proceedings of the 38th Annual Conference on African Linguistics (pp. 204-216). Somerville, MA: Cascadilla Proceedings Project.

Cook, E.-D. (1989). Is phonology going haywire in dying languages? Phonological variations in Chipewyan and Sarcee. Language in Society, 18, 235-255. DOI: http://dx.doi. org/10.1017/S0047404500013488

Dorian, N. C. (1994). Varieties of variation in a very small place: Social homogeneity, prestige norms, and linguistic variation. Language, 70(4), 631-696. DOI: http://dx.doi. org/10.2307/416324

Guy, G. R. (2005). Grammar and usage: A variationist response. Language, 81, 561-563.

Hale, M. (2007). Historical Linguistics: Theory and Method. Oxford: Blackwell.

Honeybone, P. (2011). Variation and linguistic theory. In W. Maguire \& A. McMahon (Eds.), Analysing Variation in English (pp. 151-177). Cambridge: Cambridge University Press. Extended version, downloaded [4/13/2019] at http://www.lel.ed.ac.uk/homes/patrick/varlingthr.pdf. DOI: http://dx.doi.org/10.1017/CBO9780511976360.008

Isac, D. \& Reiss, C. (2008). I-Language: An Introduction to Linguistics as Cognitive Science. Oxford: Oxford University Press.

Marlo, M. (2008). Tura verbal tonology. Studies in African Linguistics, 37(2), 153-243.

Newton, B. (1972). The Generative Interpretation of Dialect: A Study of Modern Greek Phonology. Cambridge Studies in Linguistics 8. Cambridge: Cambridge University Press.

Paster, M. (2007). Aspects of Maay phonology and morphology. Studies in African Linguistics, 35(1), 73-120. 
Paster, M. (2010). Optional multiple plural marking in Maay. In F. Rainer, W. U. Dressler, D. Kastovsky, \& H. C. Luschützky (Eds.), Current Issues in Linguistic Theory 310: Variation and Change in Morphology (pp. 177192). Amsterdam: John Benjamins. DOI: http://dx.doi. org/10.1075/cilt.310.09pas

Paster, M. (2013). An I-language approach to interspeaker variation in Maay. Paper presented at the $44^{\text {th }}$ Annual Conference on African Linguistics, Georgetown University.

Paster, M. (2018). Gender instability in Maay. In J. Kandybowicz, T. Major, H. Torrence, \& Ph. T. Duncan (Eds.). African Linguistics on the Prairie: Selected papers from the
45 th Annual Conference on African Linguistics (pp. 205218). Berlin: Language Science Press.

Paster, M., Leon, C., \& Bril, A. (2013). Collaborative linguistic research in a refugee community: Challenges and prospects. Poster presented at the Workshop on Methodology and Practice in Collaborative Endangered Language Research, Linguistic Society of America Annual Meeting, Boston.

Toivonen, I. (2007). Microvariation in Inari Saami. In J. Ylikoski \& A. Aikio (Eds.). Sámit, sánit, sátnehámit. Riepmočála Pekka Sammallahtii miessemánu 21. Beaivve 2007. Mémoires de la Société Finno-Ougrienne 253 (pp. 363-374). Helsinki: Suomolais-Ugrilainen Seura. 